\section{US call to end CFC emissions}

\section{Washington}

EUROPE will this week be under strong pressure from the United States to take steps to control the discharge of chlorofluorocarbons (CFCs) into the atmosphere. The occasion will be a meeting in Vienna, starting 23 February, of the Vienna Convention on the Protection of the Ozone Layer, of which the European Economic Community (EEC) is a member.

The US delegation is calling for a freeze on the emission of $\mathrm{CFCs}$, followed by a long-term planned reduction of emissions by as much as 95 per cent. This represents a considerable strengthening of the US position since the last round of negotiations in Geneva in December, when the participants got no further than deciding that something must be done.

Two bills introduced in the US Senate last week are designed to support the US negotiations. Both threaten to implement trade restrictions against countries that do not virtually cease production of ozonedepleting chemicals - - brominated hydrocarbons as well as CFCs. Under the terms of the bills, US production will be decreased over a 6-8 year period to a ceiling of 5 per cent of present production. The chemicals are used in refrigerants, solvents and foam packaging for food; the use of CFCs in aerosol propellants was banned in the United States in 1978 and afterwards in Switzerland, Canada and several Scandinavian countries.

The sponsors of the Senate bills, Senattors Max Baucus and John Chafee, cite a prediction of the Environmental Protection Agency that there would be 40 million excess skin cancers, resulting in 800,000 deaths in the United States alone over the next 80 years, if nothing is done to curb CFC emissions.

The situation is complicated by disagreements within the EEC about the seriousness of the problem. According to one Senate staff member, the United Kingdom and France are "not willing to admit there is a problem" of ozone depletion, while others did not attend the last round of negotiations. On the other hand, Denmark (which has no CFC industry to protect), has already banned the use of CFCs in aerosols - and may find other EEC nations taking action against it for restraint of trade.

The official US negotiating position in Vienna is less aggressive than the Senate bills. Ambassador Richard Benedick, leader of the US team, hinted last week that the United States would consider signing agreements with individual countries if no general agreement was reached.

Steven Dickman

\title{
Row takes new turn over US plagiarism of Soviet books
}

\section{London}

THE case of Dr Hollis Chen, the Ohio University professor accused of plagarism (see Nature 324, 198; 1986), has taken a new turn. Chen was accused, in the pages of the Moscow weekly Literaturnaya Gazeta, of having pirated two books by a member of the Byelorussian Academy of Sciences, incorporating them into his textbook Theory of Electromagnetic Waves. The attack was signed by the president of the Byelorussian Academy, Dr Mikolaj Barysevic, and a three-times State Prize winner, Dr Barys Sciapanau; Chen's defence was that he had never read the works in question, that he speaks no Russian, and that in any case he was writing a university textbook, not a scholarly monograph. He made no claim to originality, he said, and was not responsible for the dust-jacket blurb which suggested that this was the first time the subject was treated from a "coordinate-free" approach.

The second accusation, published in the Literaturnaya Gazeta on 28 January, and signed by two other Byelorussian scientists, raises a new charge. It attacks Chen's claim that he did not know the books, stating that a copy of one of the disputed works, the Theory of Gyrotropy, was mailed to him by the author, Dr Fiodar Fiodarau. Better known in the West under the Russian version of his name, Fedorov, Fiodarau maintains that in January 1978, Chen wrote to the Navuka $i$ Technika press in Minsk to order a book entitled The Theory of Optical Activity of which Fiodarau was a co-author. This book, although advertised, had never been published and was superseded by the Theory of Gyrotropy. Accordingly, the publishers forwarded Chen's letter to Fiodarau, who replied by sending him a copy of the latter work, says Fiodarau. Chen admits ordering The Theory of Optical Activity, but denies ever receiving any acknowledgement of his letter, let alone a book.

Following the earlier article in Nature and a similar article in the New York Times by Dr Theodore Shabad of Columbia University, the University of Ohio appointed a special committee to look into the charges. The committee was composed of the head of the department of physics and astronomy, Dr Edward Sanford, and two visiting professors, $\mathrm{Dr}$ Clayborne D. Taylor of Mississippi State University, and Dr John M. Alexander of the University of Wales.

Their findings, in effect, deny the charges that Chen had copied four chapters almost completely, and that his diagrams and some 1,000 equations were copied unchanged. They conclude that "the test of plagiarism in the case of teaching material of the type found in textbooks, therefore, as distinct from the possible plagiarism of some completely innovative theory of technique, must be a subjective one, based on the degree and extent of the similarity involved". Chen's work, they said, uses a more modern mathematical treatment, and contains far more diagrams.

Nevertheless, the committee noted some "significant similarities", although not to the extent alleged in the Soviet charges. "Involved are two sections totalling about seven pages in length which are separated by completely disparate developments of the theories involved", they say, and while clearing Chen of the charges of extensive plagiarism, they allow that "there may possibly exist some grounds to believe that Chen made use of a small amount of introductory material from a secondary source" (which itself may have derived from Fiodarau).

The committee met before the appearance of the second Literaturnaya Gazeta article, and at that time, it seems, Chen made no mention of his 1978 letter to the Byelorussian publishers. The committee accordingly met again last Friday to discuss the second batch of charges, and again decided in Chen's favour.

So far, the committee has had no chance to see the Theory of Gyrotropy, which is not readily available in the West. One wonders, indeed, whether the cause of academic enquiry might not have been better served had the Byelorussian Academy made a discreet approach to Ohio University, submitting copies of the Fiodarau books and marking the disputed passages, rather than resorting to the Soviet press and then, via the Novosti Agency in London and the Literaturnaya Gazeta correspondent in New York, ensuring that western journalists noticed the allegations.

One would have preferred, too, a more academic and less polemical approach from the Soviet side - the second Literaturnaya Gazeta referred to this correspondent as "a certain" Vera Rich, cast doubts on her professional competence, hinted that Nature's response was too rapid, and increased the number of allegedly pirated chapters from four to five. The University of Ohio, on the other hand, might have been well-advised, instead of an in-house enquiry, to refer the whole matter to some external body, perhaps to one of the many learned societies to which Chen belongs, and from which, the first Literaturnaya Gazeta article made clear, the Byelorussian Academy would like to see him expelled.

Vera Rich 